\title{
Penerapan Model Pembelajaran Predict Observe Explain untuk Meningkatkan Kemampuan Menganalisis Siklus Air Kelas V Sekolah Dasar
}

\section{Fitri Rahmawati Nugraha}

Universitas Sebelas Maret

fitrirahmawatinugraha@gmail.com

\section{Article History}

received 30/4/2021

\begin{abstract}
This research aims to improve the ability to analyze water cycle by implementing Predict Observe Explain learning model in $V$ grade students of Public Elementary Shcool Dukuhan Kerten No. 58 Surakarta Year 2020/2021. This research was a Classroom Action Research conducted in two cycles. Each cycle had four stages namely planning, implementation, observation and reflection. The pre-action results show that the students' average ability to analyze water cycle is 62,00 with a classical completeness percentage of $22 \%$ who can reach minimal completeness criteria (75). The results of cycle I show that the average ability to analyze water cycle improves to 69,31 with a classical completeness percentage of $37 \%$. The results of cycle II show that the average ability to analyze water cycle also improves to 80.28 with a classical completeness percentage of $81 \%$. The conclusion of this research is that the implementation of Predict Observe Explain learning model can improve the ability to analyze water cycle in the V grade students of Public Elementary Shcool Dukuhan Kerten No. 58 Surakarta..

Keywords: Ability Analyzing the Water Cycle, Predict Observe Explain Learning Model, Science
\end{abstract}

\section{Abstrak}

Penelitian ini bertujuan untuk meningkatkan kemampuan menganalisis siklus air dengan menerapkan model pembelajaran Predict Observe Explain pada peserta didik kelas V SDN Dukuhan Kerten No. 58 Surakarta Tahun 2020/2021. Penelitian ini merupakan Penelitian Tindakan Kelas yang dilaksanakan dalam dua siklus. Setiap siklus memiliki empat tahapan yaitu perencanaan, pelaksanaan, observasi dan refleksi. Hasil pratindakan menunjukkan bahwa rata-rata kemampuan menganalisis siklus air peserta didik adalah 62,00 dengan persentase ketuntasan klasikal $22 \%$ yang dapat mencapai kriteria ketuntasan minimal (75). Hasil siklus I menunjukkan bahwa rata-rata kemampuan menganalisis siklus air meningkat menjadi 69,31 dengan persentase ketuntasan klasikal $37 \%$. Hasil siklus II menunjukkan bahwa rata-rata kemampuan menganalisis siklus air juga meningkat menjadi 80,28 dengan persentase ketuntasan klasikal sebesar $81 \%$. Kesimpulan dari penelitian ini adalah penerapan model pembelajaran Predict Observe Explain dapat meningkatkan kemampuan menganalisis siklus air pada peserta didik kelas V SDN Dukuhan Kerten No.58 Surakarta.

Kata kunci: Kemampuan Menganalisis Siklus Air, Model Pembelajaranr Predict Observe Explain, IPA 


\section{PENDAHULUAN}

Semua makhluk yang ada di bumi ini tidak dapat dilepaskan dari air, mulai dari kebutuhan manusia di bidang rumah tangga, indsutri, pertanian, pertambangan serta pusatpembangkit listrik. Manusia harus bersyukur karena air selalu tersedia di bumi meskipun selalu digunakan sehari-hari (Azmiyawati, 2008:146). Air selalu tersedia di bumi karena adanya siklus air. Menurut Surya (2008:165) siklus air adalah perputaran air yang terjadi secara berkelanjutan dari bumi menuju atmosfer kemudian kembali lagi ke bumi. Proses siklus air terdiri dari proses penguapan (evaporasi), pengembunan (kondensasi) dan pengendapan (presipitasi). Materi ini perlu didalami dengan melakukan kegiatan menganalisis siklus air.

Menganalisis dapat diartikan sebagai kegiatan berpikir untuk menganalisa, menilai ide-ide, menemukan solusi dari sebuah permasalahan dan menentukan sebuah keputusan secara tepat dan akurat (Sternberg, 2000). Pendapat lain mengatakan bahwa menganalisis adalah kegiatan berpikir yang mengharuskan peserta didik mengidentifikasi sebuah informasi yang penting, lalu menafsirkan informasi itu ke dalam susunan yang lebih sederhana, sehingga mempermudah peserta didik untuk memahami, mengevaluasi dan menilai informasi yang telah dihimpun (Gilpin \& Wagenaar, 2005). Menganalisis atau juga berpikir analitis merupakan kegiatan berpikir tingkat tinggi yang amat dibutuhkan untuk bertahan pada abad 21. Melalui kegiatan menganalisis, seseorang dapat menemukan solusi atau menentukan pilihan dengan tepat sesuai dengan permasalahan yang dihadapinya, sehingga permasalahan yang rumit dapat dipecahkan. Pembelajaran yang ada di Indonesia rata-rata belum sampai tahap menganalisis. Pembelajaran yang ada masih sering menyasar pada tahap memahami, bahkan dalam pelaksanaannya masih banyak yang berkonsep pada tahap pembelajaran mengingat saja. Tentunya hal ini dapat membuat membuat anak bangsa tertinggal dengan perkembangan zaman. Pembelajaran berpikir analitis sangat dibutuhkan untuk mempersiapkan anak bangsa dalam menghadapi perkembangan zaman yang sangat cepat (Rose dan Nicholl, 2016:255).

Pembelajaran IPA tentang menganalisis siklus air berada di kelas V semester 2 . Pembelajaran menganalisis siklus air selama ini menunjukkan hasil kurang memuaskan. Berdasarkan hasil wawancara dan observasi yang telah dilaksanakan, peserta didik mengalami kesulitan dalam memahami materi siklus air, hal ini dikarenakan peserta didik tidak melakukan kegiatan analisis materi siklus air sehingga kedalaman materi yang dipahami peserta didik masih kurang. Kemampuan menganalisis siklus air yang rendah diperkuat dengan dilaksanakannya tes pratindakan. Hasil tes pratindakan yang telah dilakukan menunjukkan bahwa rata-rata materi IPA siklus air peserta didik sebesar 62 dengan persentase ketuntasan klasikal sebesar $56 \%$ yang mampu mencapai KKM (75). Kondisi ini harus segera mendapatkan solusi, apabila kondisi ini hanya didiamkan akan mengurangi kualitas pembelajaran sekolah. Tidak hanya itu, apabila tindakan tidak segara dilakukan, akan berpengaruh pada kemampuan menganalisis peserta didik pada masa yang akan datang. Kemampuan menganalisis harus dikuasai peserta didik untuk menjawab tantangan zaman di masa depan..

Tindakan harus segera dilakukan terhadap permasalahan rendahnya kemampuan menganalisis siklus air tersebut. Penelitian Afandi (2021) menggunakan media puzzle berbantuan kartu mampu meningkatkan kemampuan menganalisis siklus air. Penelitian Permatasari (2017) penggunaan model pembelajaran Predict Observe Explain (POE) dapat meningkatkan aktivitas dan pemahaman konsep. Kedua penelitian tersebut membuktikan bahwa penggunaan model dan media yang invatif mampu meningkatkan kemampuan menganalisis. Bertolak pada hal tersebut peneliti menerapkan model pembelajaran inovatif untuk menangani. Model pembelajaran Predict Observe Explain (POE) merupakan salah satu model inovatif yang dipilih oleh 
peneliti untuk mengatasi permasalahan menganalisis siklus air. Model pembelajaran POE mengikutsertakan peserta didik dalam memperkirakan suatu peristiwa, melakukan pengamatan melalui demonstrasi atau eksperimen, kemudian menjelaskan hasil demonstrasi dan ramalan mereka sebelumnya (Indrawati dan Setiawan, 2009: 45). Kegiatan model pembelajaran Predict Observe Explain (POE) dimulai dengan menyajikan masalah yang akan dibahasa bersama peserta didik. Peserta didik selanjutnya dituntun untuk membuat prediksi atau kemungkinan berdasarkan permasalahan tersebut. Langkah selanjutnya yaitu membuat penjelasan tentang materi tersebut sesuai dengan fakta informasi yang telah dihimpun serta menentukan kegunaan dari dugaan awal (Liang, 2015).

Definisi model pembelajarani ini yang pertama yaitu Predict, peserta didik mengamati seuatu peristiwa, kemudian peserta didik memprediksi seputar peristiwa tersebut. Observe, peserta didik melakukan penelitian tentang prediksinya sudah tepat atau belum. Explain yaitu peserta didik menjelaskan kesesuaian antara prediksi dengan hasil penelitian (Adebayo.2015).Berdasarkan penjelasan di atas rumusan penelitian ini adalah apakah penerapan model pembelajaran Predict Observe Explain (POE) dapat meningkatkan kemampuan menganalisis siklus air pada peserta didik kelas V di SD Negeri Dukuhan Kerten No.58 Surakarta tahun ajaran 2020/2021

Tujuan penelitian ini berdasarkan penjelasan di atas adalah untuk mendeskribsikan penggunaan model pembelajaran Predict Observe Explain (POE) untuk meningkatkan kemampuan menganalisis siklus air pada peserta didik kelas $\mathrm{V}$ di SDN Dukuhan Kerten No. 58 Surakarta tahun ajaran 2020/2021.

\section{METODE}

Penelitian ini adalah jenis Penelitian Tindakan Kelas. Terdapat empat prosedur penelitian pada tiap siklus yaitu perencanaan, pelaksanaan, pengamatan dan refleksi. Pelaksanaan penelitian ini di SDN Dukuhan Kerten, yang beralamat di Jalan Ahmad Yani No.24, Kerten, Kecamatan Laweyan, Kota Surakarta. Penelitian dilakukan pada bulan Januari 2021 hingga Juli 2021. Subyek penelitian ini yaitu guru kelas V dan peserta didik kelas V SDN Dukuhan Kerten tahun ajaran 2020/2021 dengan jumlah 27 peserta didik.

Data dihimpun dengan teknik wawancara dan observasi peserta didik dan guru serta nilai tes kemampuan menganalisis siklus air sebelum dan sesudah tindakan dilakukan. Sumber data pada penelitian ini adalah peserta didik kelas V SDN Dukuhan Kerten dan guru kelas V. Data penelitian terdiri dari silabus kelas V, RPP tema 8, video, foto, hasil evaluasi pembelajaran menganalisis siklus air, hasil observasi kinerja guru, aktivitas peserta didik serta hasil wawancara guru dan peserta didik,.

Teknik uji validitas data penelitian ini menggunakan validitas isi dan triangulasi. Teknik analisis data yang digunakan adalah teknik analisis data Miles dan Huberman terdiri dari empat langkah yaitu pengumpulan data, reduksi data, penyajian data dan penarikan kesimpulan (Sugiyono,2015). Penelitian berhasil jika secara klasikal peserta didik yang mendapat nilai tuntas dengan Kriteria Ketuntasan Minimal yaitu 75 mencapai $80 \%$.

\section{HASIL DAN PEMBAHASAN}

Penerapan model pembelajaran Predict Observe Explain (POE) dalam pembelajaran menganalisis siklus air memberikan manfaat pada kemampuan menganalisis peserta didik, aktivitas belajar peserta didik dan kinerja guru. Berdasarkan analisis data yang telah diperoleh, terjadi peningkatan pada setiap aspek tersebut. Hasil observasi kinerja guru dan aktivitas peserta didik dalam pembelajaran menganalisis siklus air dengan menggunakan model pembelajaran Predict Observe Explain (POE) mengalami peningkatan dari siklus I ke siklus II. Peningkatan tersebut dapat dilihat pada tabel berikut ini: 
Tabel 1. Hasil Obervasi Kinerja Guru dan Aktivitas Peserta didik Siklus I dan Siklus II

\begin{tabular}{lcccc}
\hline \multicolumn{1}{c}{\begin{tabular}{c} 
Aspek yang \\
\multicolumn{1}{c}{ dinilai }
\end{tabular}} & Siklus I & Siklus II & Siklus I & Siklus II \\
\hline Guru & 1,84 & 2,41 & Baik & Baik \\
Peserta didik & 2,77 & 3,42 & Baik & Sangat Baik \\
\hline
\end{tabular}

Tabel 1 memberikan informasi tentang hasil observasi kinerja guru dan aktivitas peserta didik dalam melaksakan kegiatan pembelajaran menganalisis siklus air dengan menerapkan model pembelajaran Predict Observe Explain (POE). Terjadi peningkatan terhadap kinerja guru dari siklus I hingga siklus II dalam pembelajaran menganalisis siklus air menggunakan model pembelajaran Predict Observe Explain (POE) siklus I mendapatkan skor akhir 1,84 tergolong dalam kategori baik. Siklus II meningkat mendapatkan skor 2,4 dan tergolong dalam kategori baik. Hasil observasi aktivitas peserta didik mendapatkan nilai rata-rata sebesar 2,77 pada siklus I dan meningkat pada siklus II menjadi 3,42. Siklus I tergolong dalam kategori baik, pada siklus II juga tergolong dalam kategori sangat baik.

Tes kemampuan menganalisis siklus air dilakukan pada pratindakan, siklus I dan Siklus II. Hasil tes pratindakan menganalisis siklus air menunjukkan bahwa terdapat sebagian besar peserta didik memperoleh nilai di bahwah KKM (75). Siklus I dan siklus II diterapkan model pembelajaran Predict Observe Explain (POE) untuk meningkatkan kemampuan menganalisis siklus air. Kegiatan pembelajaran yang dilakukan pertama adalah Prediction yaitu peserta didik membuat prediksi/ dugaan peristiwa siklus air, selanjutnya Observation atau peserta didik melakukan penelitian atau pengamatan tentang peristiwa siklus air yang bersumber pada video, bagan, modul dan hasil penelitian tentang siklus air, dan yang terakhir Explanation atau peserta didik menjelaskan kesesuaian antara dugaan (prediksi) dengan yang sesungguhnya terjadi. Hasil evaluasi pratindakan, siklus I dan siklus II kemampuan menganalisis siklus air seperti pada tabel 1 berikut:

Tabel 2. Hasil Evaluasi Kemampuan Menganalisis Siklus Air Pratindakan, Siklus I dan Siklus II

\begin{tabular}{clccc}
\hline No & Keterangan & Pratindakan & Siklus I & Siklus II \\
\hline 1 & Nilai rata-rata kelas & 62 & 69,31 & 80,5 \\
2 & Nilai tertinggi & 80 & 88 & 95 \\
3 & Nilai terendah & 30 & 43 & 60 \\
4 & Ketuntasan klasikal & $22 \%$ & $37 \%$ & $81 \%$ \\
\hline
\end{tabular}

Berdasarkan informasi yang didapat dari tabel 2 terjadi peningkatan dari pratindakan, siklus I hingga siklus II terjadi pada nilai rata-rata kelas, nilai tetinggi, nilai terendah dan ketuntasan klasikal. Nilai rata-rata kelas meningkat dari 62 pada pratindakan, meningpuikat menjadi 69,31 pada siklus I, kemudian meningkat lagi pada siklus II menjadi 80,5. Nilai tertinggi juga mengalami peningkatan dari 80 pada pratindakan meningkat menjadi 88 pada siklus I dan meningkat lagi menjadi 95 pada siklus II. Nilai terendah mengalami peningkatan dari 30 pada pratindakan menjadi 43 pada siklus I dan mengalami peningkatan menjadi 60 pada siklus II. Ketuntasan klasikal juga mengalami peningkatan dari pratindakan peserta didik yang tuntas adalah 
$22 \%$, meningkat pada siklus I menjadi 37\%, dan meningkat lagi pada siklus II menjadi $81 \%$. Berdasarkan pencapaian yang telah diperoleh pada siklus II bahwa terdapat $81 \%$ peserta didik yang telah memenuhi KKM sesuai dengan indikator kinerja penelitian, peneliti mengakhiri tindakan pada siklus II.

Evaluasi kemampuan menganalisis siklus air pada siklus II terjadi peningkatan skor rata-rata nilai menjadi 80,5. Hasil tersebut dikategorikan baik apabila dibandingkan dengan penelitian relevan. Penelitian yang dilakukan oleh Afandi ratarata nilai pada siklus II mencapai 90 , hasil yang diperoleh memanglah hampir sama, namun variabel $X$ yang diterapkan berbeda. Dibandingkan dengan penelitian dari Permatasari (2017) dengan jumlah rata-rata nilai pada siklus II yang lebih rendah yaitu 73,94, hal ini dikarenakan perbedaan materi pembelajaran yang dijadikan sebagai variabel Y.

Berdasarkan pemaparan di atas, penggunaan model pembelajaran Predict Observe Explain (POE) dapat meningkatkan kemampuan menganalisis siklus air pada peserta didik kelas V SDN Dukuhan Kerten No. 58 Surakarta tahun 2020/2021. Berdasarkan pada pemapara hasil penelitian yang telah diperoleh, model pembelajaran POE dapat meningkatkan kemampuan menganalisis peserta didik melalui kegiatan Predict, karena peserta didik memprediksi perisitiwa yang dipaparkan oleh guru sesuai dengan kemampuan awalnya. Kemampuan menganalisis juga lebih diperdalam dalam tahap Observe, yaitu kegiatan mencari kebenaran prediksinya melalui eksperimen, mengukur, menimbang, dan mencoba. Tahap ini peserta didik membuktikan prediksinya dapat saling bertanggung jawab atas hasil pengamatannya tentang siklus air. Peserta didik didorong untuk lebih aktif dalam memberi pertanyaan atau tanggapan melalui tahap Explain. Hal tersebut sesuai dengan pernyataan Adebayo (2015) bahwa model pembelajaran POE mampu mengurangi kesalahpahaman pada materi sains dan mampu memupuk kemampuan peserta didik berpikir kritis serta anlitis. Latihan-latihan soal dari kegiatan pembelajaran dengan menerapkan model pembelajaran POE dapat membuat peserta didik lebih terlatih untuk menyelesaikan pertanyaan yang merangsang peserta didik untuk berpikir dengan analitis. Hal tersebut sesuai dengan pernyataan dari Rose \& Nicholl (2016:271) menjelaskan bahwa kemampuan menganalisis dapat diajarkan, dipelajari dan dikembangkan melalui berlatih secara terus-menerus.

\section{SIMPULAN}

Berdasarkan pada hasil penelitian dan pembahasan yang telah dilakukan pada siklus I dan siklus II, dapat ditarik kesimpulan bahwa model pembelajaran Predict Observe Explain (POE) dapat meningkatkan kemampuan menganalisis siklus air peserta didik kelas V SDN Dukuhan Kerten No. 58 Surakarta tahun ajaran 2020/2021. Implikasi teoretis pada penelitian ini adalah untuk meningkatkan kemampuan menaganalisis siklus air, menambah wawasan tentang model pembelajaran POE, dan dijadikan referensi dalam menerapkan model POE. Implikasi praktis penelitian ini adalah dapat menjadi sebuah referensi untuk menemukan model pembelajaran yang tepat untuk mengatasi masalah yang serupa dengan penelitian ini.

\section{DAFTAR PUSTAKA}

Adebayo, Famakinwa. (2015) Generative and Predict-Observe-Explain Instructional Strategies: Towards Enhancing Basic Science Practical Skills of Lower Primary School Pupils. International Journal of Elementary Education, 1 (4), 86-92.

Afandi, A. N. H. (2021). Peningkatan Kemampuan Menganalisis Siklus Air Melalui Media Puzzle Berbantuan Kartu Siklus Air Pada Siswa Kelas V SDN Besowo 2 Kecamatan Kepung Kabupaten Kediri. Jurnal Pendidikan IImu Fisika, 1 (2), 71 80. 
Azmiyawati, Choiril dkk. 2008. IPA Salingtemas untuk Kelas V SD/MI. Jakarta: Pusat Perbukuan Depatemen Pendidikan Nasional.

Gilpin, A., \& Wagenaar, R. (2006). Approaches to Teaching, Learning and Assessment in Competence Based Degree Programmes. University of Deusto Press, 91 118.

Indrawati, dan W. Setiawan. 2009. Pembelajaran Aktif, Kreatif, Efektif, dan Menyenangkan untuk Guru SD. Bandung: PPPPTK IPA

Liang, J.C. (2011). Using POE to Promote Young Children's Understanding of the Properties of Air. Asia-Pasifik Journal of Rereach in Early Childhood, 5 (1), 45-68.

Permatasari, Obimita. (2021) . Penerapan Model Pembelajaran Predict-ObserveExplain Berbasis Kontekstual Untuk Meningkatkan Aktivitas dan Pemahaman Konsep. Jurnal Tindakan Kelas, 2 (2), 50-53.

Rose, C. \& Nicholl, M. J. 2016. Accelerated Learning, Cara Belajar Cepat Abad XXI. Bandung: Penerbit Nuansa.

Sternberg, R. J. 2000 . Practical Intelligence in Everyday Life. Cambridge: Cambridge University Press.

Sugiyono. 2015. Metode Penelitian Pendidikanm: Pendekatan kuantitatif, Kualitatif, dan $R \& D$. Bandung: Alfabeta.

Surya, Yohanes. 2008. IPA Asyik, Mudah, dan Menyenangkan 4A. Jakarta:Grasindo. 